\title{
A veterinary perspective on One Health in the Arctic
}

\author{
Christian Sonne ${ }^{1 *} \mathbb{0}$, Robert James Letcher ${ }^{2}$, Bjørn Munro Jenssen ${ }^{1,3,4}$, Jean-Pierre Desforges ${ }^{1}$, Igor Eulaers ${ }^{1}$, \\ Emilie Andersen-Ranberg ${ }^{1}$, Kim Gustavson ${ }^{1}$, Bjarne Styrishave ${ }^{5}$ and Rune Dietz ${ }^{1}$
}

\begin{abstract}
Exposure to long-range transported industrial chemicals, climate change and diseases is posing a risk to the overall health and populations of Arctic wildlife. Since local communities are relying on the same marine food web as marine mammals in the Arctic, it requires a One Health approach to understand the holistic ecosystem health including that of humans. Here we collect and identify gaps in the current knowledge of health in the Arctic and present the veterinary perspective of One Health and ecosystem dynamics. The review shows that exposure to persistent organic pollutants (POPs) is having multiple organ-system effects across taxa, including impacts on neuroendocrine disruption, immune suppression and decreased bone density among others. Furthermore, the warming Arctic climate is suspected to influence abiotic and biotic long-range transport and exposure pathways of contaminants to the Arctic resulting in increases in POP exposure of both wildlife and human populations. Exposure to vector-borne diseases and zoonoses may increase as well through range expansion and introduction of invasive species. It will be important in the future to investigate the effects of these multiple stressors on wildlife and local people to better predict the individual-level health risks. It is within this framework that One Health approaches offer promising opportunities to survey and pinpoint environmental changes that have effects on wildlife and human health.
\end{abstract}

Keywords: Contaminants, Greenland, Hg, Humans, Inuits, Mercury, Persistent organic pollutants, Polar bears, POPs, Seals, Sled dogs, Whales

\section{Background}

One Health aims to improve health and well-being through the prevention of risks and the mitigation of effects of crises that originate at the interface between humans, animals and their various environments (http:// www.onehealthglobal.net). Given the close relationship between wildlife, sled dogs and humans in the North Atlantic, in combination with long-term biomonitoring programs using multiple veterinary tools over the last three decades, an Arctic One Health approach requires focus on few key species and study areas that interlink wildlife, human and ecosystem health. The present review will therefore discuss clinical and veterinary studies on polar bears (Ursus maritimus), ringed seals (Pusa

\footnotetext{
*Correspondence: cs@bios.au.dk

${ }^{1}$ Department of Bioscience, Arctic Research Centre (ARC), Aarhus

University, Faculty of Science and Technology, Frederiksborgvej 399, PO

Box 358, 4000 Roskilde, Denmark

Full list of author information is available at the end of the article
}

hispida), narwhals (Monodon monoceros), killer whales (Orcinus orca), domestic sled dogs (Canis familiaris), and humans (Homo sapiens), and how shared information on these provide a base from which One Health can be operated. The focus will be on exposure of Arctic wildlife and Inuit populations to long-range transported contaminants and its interactions with climate change and infectious diseases (zoonoses).

\section{Search strategy}

We conducted this literature review to give a systematic overview of the current knowledge on environmental contaminants and zoonosis in the Arctic and how it links to climate change in a multiple stressors framework. From our own working knowledge in the field, we identified "persistent organic pollutants (POPs)", "mercury $(\mathrm{Hg})$ " and "zoonoses" relevant for the Arctic and the link to "climate change" as overall themes/keywords. We used ScienceDirect, PubMed, Google, Google Scholar, ISI 
Web of Knowledge/Web of Science and Springer Link to locate peer-reviewed scientific articles and reports, using the thematic keywords "immune", "endocrine", "neuro", "bone", "diseases" and "multiple stressors" either alone or in combination. We also used dissertations and AMAP reports to obtain information from the grey literature. Although we attempted to be systematic within the scope of the review, we acknowledge that this is not an exhaustive representation of all the material that may exist in the scientific literature.

\section{The arctic environment as a sink for pollutants}

Hunting and fishing have always been an important part of Arctic human existence in this harsh northern environment [1-6], and their intensity has increased with a growing Arctic human population bringing along more effective hunting methods, including larger and faster boats and fishing vessels, riffles and gillnets. Adding to these local stressors on Arctic ecosystems, anthropogenic pollution has become a ubiquitous problem that is particularly relevant in the Arctic environment [6-8]. In addition to elevated mercury $(\mathrm{Hg})$, an array of anthropogenic chlorinated, brominated, and fluorinated persistent organic pollutants (POPs), all alien substances, have been introduced to the Arctic [1, 7, 9-14]. More specifically, the 1850 s marked the period of early industrialization and was associated with elevated $\mathrm{Hg}$ emissions [10], whereas the onset of the 1940s marked the onset of largevolume worldwide use of industrial chemicals and pesticides. POPs and $\mathrm{Hg}$ typically originate from industrial and household emissions at temperate regions and are transported via global atmospheric and oceanic pathways that result in deposition in the Arctic environment $[6,7$, 9, 11, 12, 15].

Arctic fish and wildlife rely on energy-rich fatty tissues as their main energy source in the harsh Arctic environment $[16,17]$. Fatty tissues typically host various natural lipophilic compounds, such as specific vitamins (A and D) and endogenous steroid hormones transported by portal and periphery blood supply among others $[8,18-$ 23]. However, most POPs and methyl- $\mathrm{Hg}$, the bioavailable chemical from of $\mathrm{Hg}$, are highly lipophilic as well and are therefore readily stored in lipid-rich tissues. Additional low excretion of these compounds results in a net intake of POPs and Hg over time, referred to as bioaccumulation, and is moreover transferred from prey to predator along the food chain resulting in biomagnification. As a result, apex predators such as polar bears, Arctic fox (Vulpes lagopus), seal spp., whale spp. and seabird spp., are exposed to the highest concentrations occurring the Arctic environment, already a major sink for POPs and $\mathrm{Hg}$ as described above. Finally, indigenous northerners and their dogs are ultimate sinks due to their traditional consumption of the aforementioned wildlife [7, 13, 14, 24, 25]. Newer perfluorinated compounds [poly- and perfluoralkyl substances (PFASs)], in particular perfluorooctane sulfonate (PFOS) and other long-chained polyand perfluorocarboxylic acid (PFCAs) are proteinophilic and also biomagnify due to high resistance to biological degradation [7].

Long-range transported pollutants have been extensively monitored in the Arctic due to the high exposure of Inuit populations, resulting from their consumption of a marine diet consisting especially of apex marine predators high in contaminants $[2,3,6]$. Such biomonitoring activities have shown that, among these POPs, polychlorinated biphenyls (PCBs) continue to dominate and are of the greatest exposure concern, despite their ban decades ago [7]. However, other high-concentration POPs, amongst which organochlorine pesticides (OCPs), brominated flame retardants (BFRs), PFASs, and $\mathrm{Hg}$ can also be found at concentrations that raise concerns for the health of top predators and humans [7, 11, 26-28].

\section{Arctic wildlife and human health}

POPs and Hg pose a health threat to Arctic top predators and humans because the compounds and their biotransformation metabolites have structural similarities to endogenous compounds. These anthropogenic compounds have been classified as endocrine disruptors or cellular toxicants acting via non-endocrine pathways, and thus negatively affect immune and neuro-endocrine functioning, growth and development, reproduction and general fitness $[7,8,29]$. Since the compounds potentially target different organ-tissues, the dietary exposure causes chronic and combined stress manifested through several health effects at the organism level $[8,30,31]$.

There is evidence that high exposure poses a great risk to neonatal individuals during critical periods of development. Seasonal cycles of energy requirements for fasting, breeding, lactation, and migration lead to increased intake or catabolism of adipose tissue causing pulsed exposure to bioavailable contaminants circulating in the blood [32, 33]. In polar bears, for example, up to $70 \%$ of the total organochlorine body burden is transported from mother to offspring during lactation, resulting in cub adipose tissue concentrations that are approximately three times higher than those in their mothers [32, 3437]. A female polar bears' very first cubs are believed to be especially vulnerable since high contaminant exposure can affect normal development and growth [7, 8, 31]. In a meta-study, it has recently been modelled that chlorinated and brominated POPs, singularly or collectively, were far better predictors of declines in population densities in 14 polar bear subpopulations than were human population density, harvest rate and sea ice extention 
[38]. Indeed, circumarctic polar bear subpopulations are under influence of immunological, reproductive and carcinogenic consequences from POP exposure [27]. From a population conservation point of view, contaminants that reduce pregnancy, fecundity and survival in both males and females are among the most important to monitor in different Arctic subpopulations of polar bears, as well as other top predators and northerners relying on the same food web [39, 40].

East Greenland polar bears, killer whales, narwhals and ringed, harp (Pagophilus groenlandicus) and hooded seals (Cystophora cristata) carry very high concentrations of POPs and $\mathrm{Hg}[7,11,12,15,41]$. Since Greenlanders in this region traditionally ingest significant quantities of adipose tissue from these species, they are among the Arctic people carrying the highest POP burdens [5, 6, $43,44]$. Such high exposure is likely to pose a health risk based on available literature on dioxin toxic equivalency factor (TEQ) and tolerable daily intake (TDI) guidelines [44, 45]. Human exposure to contaminants in Greenland has been evaluated from chemical analyses of prey species and food intake $[5,46,47]$, showing that the TDI was exceeded for chlordane (CHL) by a factor of 3-6, while PCB exposure did not. However, none of these studies reported on polar bear and ringed seal blubber important to people's exposure in East Greenland, where POP loads are known to be four times larger than in west Greenland. According to Nielsen et al. [48] it is recommended that Greenlanders reduce their exposure to $\mathrm{PCBs}$ and $\mathrm{CHL}$ by reducing their blubber intake. The Arctic Monitoring and Assessment Programme (AMAP) is therefore concerned about Arctic human health within a contaminant exposure context and their studies do support observations that Greenland hunters are particularly exposed to high PCB concentrations due to frequent ingestion of polar bear, killer whale, narwhal and seal tissues $[6,44$, 49-51]. Studies from the Russian Arctic have shown that dioxin, furans and PCB exposure of neo- and prenatal children exceeded TEQ TDI levels by up to 33 times in the year 2000 [5, 52]. It has been shown that blood concentrations of PFASs including PFOS in male Inuits from East Greenland can be two to three times higher as compared to the Faroese population where local exposure has already been attributed with effects on the immune system [53-55].

Although certain PFASs have been associated with developmental and hormonal effects, immunotoxicity, and tumour growth in rodents [56], the impact of these compounds on human health appear to be inconclusive $[56,57]$. Of the PCBs found in Greenlanders, the congeners CB-77, CB-126 and CB-169 attain a coplanar configuration similar to the very toxic dioxins and furans, and are in fact commonly found in Arctic wildlife [3, 5,
58]. These coplanar PCB congeners are characteristically highly potent inducers of aryl hydrocarbon hydroxylase activity [3, 5]. Furthermore, for Greenlanders, significant correlations were found between blood contaminant concentrations and calculated daily intake of POPs [51]. $\mathrm{Hg}$ exposure of Inuit people is also of great health concern and has been recognised as a neuro-endocrine and immune health problem in the societies of Faroe Islands, West Greenland (Avanersuaq, Thule) and Canada [6, 11, 59].

\section{Biomonitoring of wildlife health}

Several of the environmental contaminants, such as PCBs and $\mathrm{Hg}$ are regulated by international agreements over the last 15 years through international treaties and conventions including the Stockholm Convention on POPs (http://chm.pops.int) and Minamata Convention on $\mathrm{Hg}$ (http://www.mercuryconvention.org). However, over the last two decades, the concentrations of the highly toxic PCBs, chlordane pesticides and $\mathrm{Hg}$ have remained essentially unchanged or even increased in polar bears inhabiting contaminant hot spots, such as Greenland and Hudson Bay [10, 12-14, 60, 61]. This is likely due to climate change effects on food web interactions, generational transfer, and continued secondary and unintentional emissions [12, 13, 17, 62]. For Hg, body burdens even appear to be continuously increasing in most top predators in the central Arctic reaching up to 20-fold baseline levels of pre-industrialisation $[10,11,60,63]$.

For three decades the AMAP program and associated subprograms have therefore monitored the health of Arctic wildlife and humans $[1,3,5-7,41,60]$. For the purpose of studying contaminant concentrations, spatial and temporal trends, and human exposure, these programs have used ringed seals and polar bears as key monitoring species $[7,64]$. From the East Greenland region, a large number of organ-tissue samples from polar bears have been obtained since the 1980s as part of the traditional hunt $[12,42]$. Likewise, from Svalbard, Canada and Alaska, adipose tissue and blood has been archived, facilitating the spatial and temporal trends which are further supported by similar samples from ringed seals [7]. With respect to East Greenland polar bears, histopathological, gross morphological and bone composition and morphological investigations have been carried out since 1999 [8, 31, $65,66]$. These studies have provided a unique opportunity to investigate the potential organ-specific effects of POP exposure [8]. Similar to polar bears, analyses of bone density and histopathology have been carried out on West Greenland ringed seal populations $[67,68]$ and on Alaska polar bears, ringed seals and whale spp. [69-72].

Interpretations and conclusions in wildlife health studies linked to contaminant exposure are typically based on 
correlational and descriptive interpretations, unavoidably confounded by a plethora of factors affecting the physiological state of a free-ranging animal. To improve the understanding of the effects of exposure to real-world contaminant cocktails experimental exposure studies have been performed on sled dogs and domesticated Arctic foxes, being possible surrogate model species for Canidae spp. In captive sled dogs and Arctic fox studies, which both included a cohort fed a naturally POP contaminated diet of minke whale (Balaenoptera acutorostrata) blubber, it has been possible to define and compare POP exposed and unexposed reference groups in direct relation to an array of effects such as on reproductive organs and other internal organs, the skeletal system, immune and endocrine systems, and POP dietary accumulation, biotransformation and toxicokinetics $[7,8,31]$.

\section{Biological effects}

In the following sections we review the available literature of One Health in the Arctic (Fig. 1). We present and discuss the results from empirical studies of wildlife and compare these with controlled studies of sledge dogs and arctic foxes in the context of One Health and health effects in humans. The following sections are divided into first specific organ-systems and after that the relatively sparse information on multiple effects health effects are presented and discussed.

\section{Chronic diseases}

Chronic diseases, including diabetes, upper respiratory and recurrent middle ear infections, cancer, and osteoporosis, are becoming an epidemic in the Arctic and may be partially caused by chronic POP exposure and associated endocrine disruption $[3,5,73]$. It is apparent that subsistence hunters in East Greenland are exposed to mixtures of POPs that include both toxic parent compounds and also their derived metabolites [74]. Some POPs can induce (hepatic) cytochrome (CYP) 450 enzymes in Arctic people that may interfere with normal metabolic processes and homeostasis of various intrinsic hormones and vitamins influencing immunity and reproduction $[1,3,5,75,76]$. Likewise, Sandau et al. [77] found that metabolism of PCBs was significantly negatively correlated with thyroid hormones, namely free thyroxine, in northern peoples in the Ungava region in northern Quebec, Canada. These findings of associations between POP exposure, induction of CYP-450 enzymes, and changes in thyroid hormone concentrations, may play a role in the development of chronic diseases [5].

\section{Bone mineral density}

Studies of polar bears suggest that osteoporosis may be a problem for especially the male bears that do not have the evolutionary physiological mechanisms that females have, putting them at high risk of POP related bone

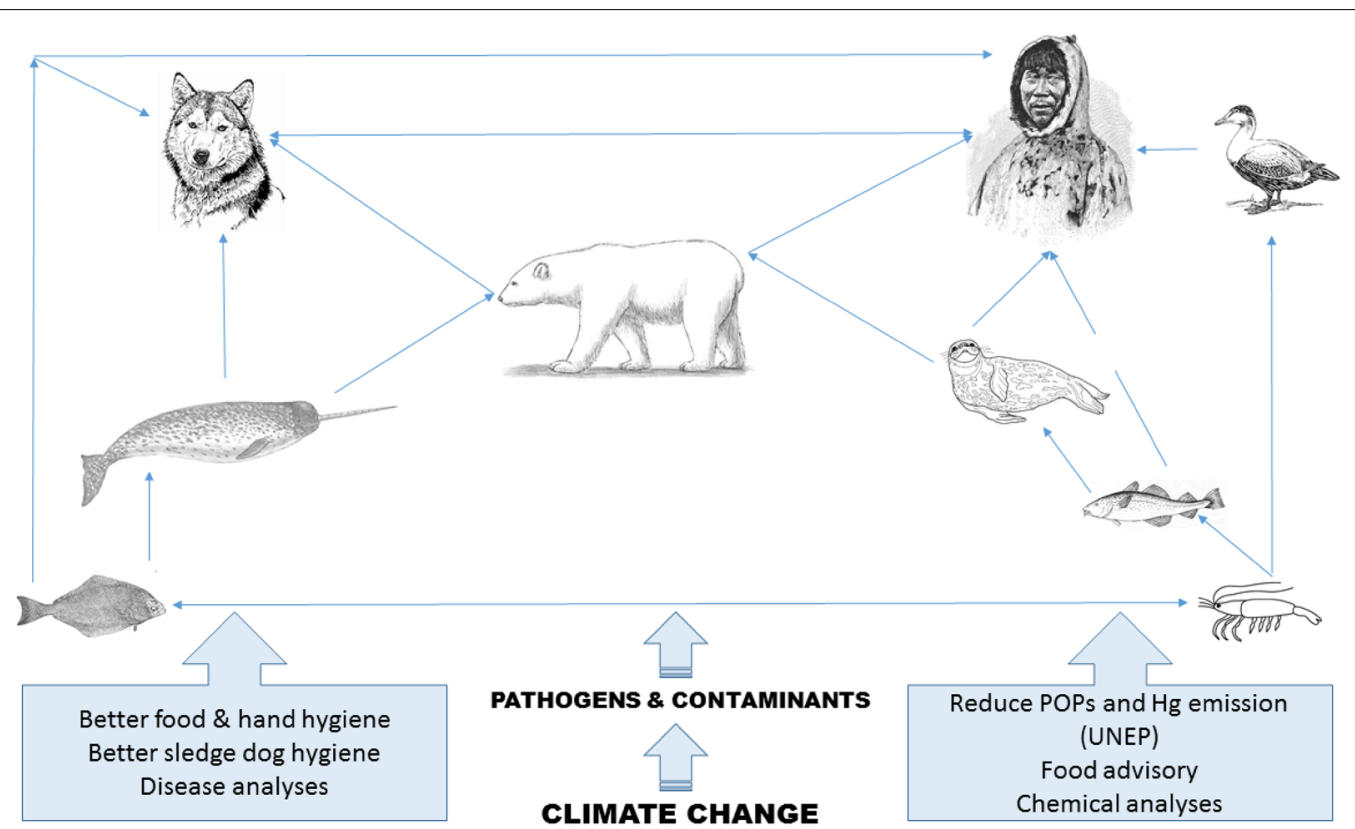

Fig. 1 A simplification of the marine food web and One Health in the Arctic. Climate change affect the presence of pathogens and composition of contaminants in Arctic wild life that is handled and eaten by Inuits and sled dogs transferring contaminants and pathogens into the local societies. Inuits and sled dogs share microbiomes which increases the risk of zoonotic infections. Actions to be taken is given in callouts 
mineral density declines $[8,66,78]$. The studies of polar bears have shown reductions in bone mineral density due to PCB exposure all supported by studies on seals in the Baltic Sea and alligators in Florida, USA [79-81].

A single study has been published on osteoporosis in relation to POP exposure in Greenlanders [82]. The study focused on quantitative ultrasound parameters (QUS) at the right calcaneus of 153 people from Southwest Greenland and found blood plasma CB-153 concentrations strongly and negatively associated with the three QUS parameters. While the relationship was no longer significant when normalizing for age and weight, people in Southwest Greenland belong to some of the lowest POP exposed Greenlanders and effects on bone composition are therefore not likely to occur $[5,6]$. Another study of Cree women from Eastern James Bay in Canada showed that bone stiffness index was negatively associated to blood concentrations of CB-105 and CB-118 [83].

\section{Endocrine disruption}

Endocrine disruption from POP exposure is likely to be a challenge in Arctic wildlife [30, 84]. Polar bears have been in focus over the last decades and both steroid hormones and thyroid hormones seem to be impacted by POP parent compounds and their metabolites, mimicking hormone activity in both the transport pathways and receptor mechanisms and affecting overall health and survival $[8,30]$. These investigations have been backed up by controlled experiments on sled dogs and Arctic foxes $[8,84]$. Likewise, in Inuit peoples, disruption by POPs of the thyroid and steroid hormone endocrine axis is influencing physiological endpoints with effects on reproduction, cancer, and immunity $[6,85]$.

Studies on polar bears from Svalbard indicate that plasma steroid levels may be affected by POP exposure, particularly $\mathrm{PCBs}$ and their hydroxylated metabolites (OH-PCBs). In females, pregnenolone and androstenedione in the blood appeared to be significantly negatively correlated to several hydroxylated PCBs [86], indicating that these POPs may affect early or perhaps rate-limiting steps in steroidogenesis. The data also indicated that CYP-17 may be a target for OH-PCBs and consequently the reproductive potential of female polar bears. PCBs also appear to affect male plasma steroids, in particular androgen levels in Svalbard polar bears [87]. Concentrations of the most masculinizing steroids, dihydrotestosterone and testosterone, were negatively correlated to levels of a large number of PCB congeners.

\section{Reproductive organs}

Studying reproductive organs in wildlife is often based on necropsy samples as clinical investigations are rather difficult. Necropsy of human reproductive organs from
Arctic populations has for ethical reasons not been studied, though the investigation of endocrinology and reproductive organs in wildlife and domesticated species (sled dogs and Arctic fox) can give some important information. For example, the presence of orchitis in polar bear testes [88] may be of importance while studying testicular dysgenesis syndrome in Inuits. Seasonal hormone and semen production in Arctic fox was found to be affected by POPs $[89,90]$. Similarly, there are indications that the size of polar bear penis bone, testicles and ovaries may be inversely correlated to PCB concentrations [66, 88]. Such information may be of use in human medicine when autopsies are not an option and when POPs are suspected of having endocrine disruptive effects in humans.

\section{Immune effects}

Environmental contaminants have been shown to modulate all measurable aspects of cellular and humoral immunity in marine mammals [89]. Resistance against acute and chronic diseases also depends on the optimal function of the immune system [91, 92]. For years, POPs have been known to modulate immunity, and while the mechanisms of immune suppression are not fully understood, it includes both humoral cell-mediated systems [3, 92-95]. Several studies have reported immune effects in Arctic wildlife, including polar bears, ringed seals, sled dogs and Arctic foxes [8], demonstrating that contaminants are reaching levels that can cause significant changes in physiology and immune fitness, with important consequences for resistance to disease.

Polar bear immunity was assessed in a comprehensive study in Svalbard and Hudson Bay, and negative associations were found between PCB exposure and serum immunoglobulin G (IgG) levels, antibody titres against influenza virus and reovirus following immunizations, and lymphocyte proliferation [96, 97]. In a controlled study on Greenland sled dogs, exposed pups, but not adults, showed reduced and delayed IgG antibody production with circulating levels of IgG in all pups correlating to blood concentrations of several POPs [8]. Hepatic mRNA expression of interleukin-1 $\beta$ (IL-1 $\beta$ ), an important pro-inflammatory cytokine, in ringed seals from Svalbard were positively correlated with hepatic POP levels [98]. Similarly, hepatic IL-1 mRNA expression was positively correlated with blubber PCB burdens in 41 ringed seals in northern Labrador, Canada [99]. These studies illustrate that in vivo real life exposure to contaminants cause measurable changes in immune function in Arctic wildlife, and thus likely humans.

In vitro experiments, where immune cells are exposed to contaminants under laboratory conditions in order to characterise effect levels, have also been carried-out in Arctic wildlife species. East Greenland ringed seal 
leukocytes were exposed to four PCB congeners (CB$138,-153,-169$, and -180 ) and two PFASs, i.e. PFOS and perfluorooctanoic acid (PFOA), and it was found that PCBs but not PFASs cause significant suppression of lymphocyte proliferation at relevant environmental concentrations for seals [100]. Beluga whale (Delphinapterus leucas) leukocytes were also used to show that low levels of $\mathrm{Hg}$ exposure can cause significant reductions in lymphocyte proliferation and intracellular thiol production, and significant induction of metallothionein [101]. Altogether, studies of free-ranging animals and in vitro experiments suggest high contaminant loads in the Arctic can induce immune suppression which affect the ability to respond to intruding infectious pathogens as previously suggested for marine mammals [7, 8, 31, 89] and Inuit and other northern peoples [6]. For example, prenatal exposure to PCBs has been suspected to play a role in the relatively high incidence of acute respiratory infections and middle ear inflammation in Inuit children [6, 102-106].

\section{Neurological effects}

Multiple environmental contaminants can cross the blood-brain barrier and exert effects on the brain functioning thus causing neurobehavioral effects. Through various mechanisms, contaminants can influence mating and other reproductive behaviours, motivation, communication, aggression, dominance and other social behaviours, as well as learning and other cognitive abilities $[29,107]$. Field studies of behavioural effects of POPs in polar bears are difficult to conduct due to logistical and ethical constraints. However, several POPs reported in brain tissue of polar bears [74, 108-112] are confirmed or suspected developmental neurotoxicants in humans and experimental animals [29, 107, 113, 114]. POPs might affect brain function or development through many mechanisms, for instance by interacting with brain neurotransmitter systems [113]. Also, the ability of some POPs to induce epigenetic changes could present a mechanistic pathway of neurodevelopmental perturbations [115-117]. Associations between neurochemical and epigenetic biomarkers and $\mathrm{Hg}$ levels in brain tissue have been reported for polar bears [11, 118, 119]. Despite relatively low concentrations of $\mathrm{Hg}$, significant negative correlations were found between both $\mathrm{Hg}$ concentrations and $N$-methyl-D-aspartic acid (NMDA) glutamate receptors. NMDA glutamate and genomic methylation is important for animal health, behaviour, reproduction, and survival, and their reduction may have populationlevel effects for polar bears [120].

Another proposed mechanism of developmental neurotoxicity is through thyroid hormone disruption; thyroid hormones are essential for proper neurodevelopment of the foetus and early neonate $[121,122]$. Thus, the high levels of POPs reported in 4-month old polar bear cubs [34] and their associated thyroid disrupting properties in cubs [123, 124] raises concern for neurodevelopmental effects in polar bears. The relatively high concentrations of several POPs reported in polar bear brains may cause adverse effects, with a possible heightened susceptibility during the more sensitive foetal and neonatal stages of brain development $[29,125]$. Similarly to humans, this could alter behavioural traits and reduce cognitive abilities related to memory and learning in offspring. For polar bears, this could functionally reduce hunting skills or alter mating behaviour, and thus ultimately affect reproduction and survival.

\section{Multiple stressors}

In the previous section we discussed the important risk posed by environmental contaminants in Arctic wildlife and human populations for a wide range of physiological health endpoints. Arctic ecosystems, however, are being stressed by more than contaminants, resulting in a situation of multiple cumulative stress for wildlife and humans. Two major additional aspects to consider in the study of Arctic health is climate change and infectious diseases. Climate change has a duel impact, acting through alteration of food web pathways for contaminants $[61,126]$ and spreading and virulence of zoonotic diseases associated to sea ice conditions [127-129]. A pollution induced increase in disease rates due to immunotoxic effects of POPs and $\mathrm{Hg}$ can increase the likelihood and risk of disease transfer from animals to humans (zoonoses) as the proportion of infected Arctic wildlife increases [30, 89, 130-132]. A large volume of marine and terrestrial wildlife is consumed by humans in the Arctic, often raw and inadequately frozen, and this likely increases the risk of zoonotic diseases [8].

\section{Climate change and contaminant exposure}

Arctic wildlife have received considerable focus as they, depending on the regional subpopulation, are threatened most dramatically by climate change due to observed and projected loss of sea ice, which has important implications for ice-associated hunters like polar bears [133135]. Modeling has shown that southernmost polar bear subpopulations in the Hudson Bay are at greatest risk, and will struggle to persist throughout this century [136]. In fact, models have also predicted two-thirds of the world's polar bears could disappear if greenhouse gas emissions continue to increase as predicted [134, 137]. This has been linked to the occupation of large home range sizes and the requirement of higher energetic costs and thus higher feeding rates, which can lead to increasing blood PCB concentrations $[138,139]$. In 
some regions, the decline of sea ice extent has resulted in changes in the presence of seal species that polar bears prey upon, and this has been shown to cause increased bioaccumulation of certain POPs as more contaminated prey are being consumed [61, 140]. Dietary shift towards feeding on plants, berries and caribou (Rangifer taran$d u s)$ and seabird eggs [141-143] will most likely decrease and increase, respectively, the exposure to POPs. Furthermore, climate warming induced migration of warm water adapted fish species [144, 145] may act as biovectors increasing contaminant levels in marine Arctic ecosystems [146, 147], ultimately causing increased bioaccumulation and biomagnification of these compounds to humans and other high trophic marine wildlife [30, 126]. McDonald et al. [147] conducted a review on ecological impacts of global climate change on POP and $\mathrm{Hg}$ pathways and exposures in arctic marine ecosystems, and documented that lower sea ice extent mediated dietary changes were associated with higher contaminant levels in some populations of polar bears, ringed seals, and thick-billed murres (Uria lomvia), but the influence of changing trophic interactions on POP levels and trends varied widely in both magnitude and direction.

\section{Climate change and infectious diseases}

Climate change not only threatens to alter contaminant dynamics by changing Arctic ecosystems, but these same factors influencing the presence and extent of different species in the Arctic will have implications for the introduction of novel infectious diseases to the region. Climate change has been deemed the most important factor in the emergence of infectious diseases, and nowhere else in the world is climate change occurring as fast as in the polar regions [148, 149]. A warming climate may profoundly affect disease dynamics in the Arctic by changing the species composition and northward invasion of disease vectors and transport of pathogens $[149,150]$. In addition, increased survival of infected animals during milder winters may further increase the risk of pathogen reservoir in marine mammals including that of zoonosis $[149,150]$. Moreover and as discussed above immunotoxic contaminants may increase disease-related mortality and morbidity of Arctic marine mammals [129].

\section{Perspectives and recommendations}

Further efforts are required to understand the toxicokinetics and toxicodynamics of POPs and $\mathrm{Hg}$ in Greenland wildlife and peoples in this changing Arctic in order to better predict the individual-level health risks associated with contaminant exposure. Arctic top predators are sentinels for humans as they consume the same diet and act as potential vectors for zoonotic transfer to humans due to harvesting. Combining correlational studies on wildlife health with experimental work on surrogate species, such as the sled dog, will allow better understanding of the proximate toxic pathways behind exposure to contaminants and infectious diseases, their interactions, and the driving role of a rapidly changing climate. Doing this offers a promising One Health approach to survey and pinpoint environmental change and multiple stressors that may have effects on wildlife and human health $[7$, $8,31,151-153]$. The warming Arctic climate is suspected to influence abiotic and biotic long-range transport and exposure pathways of contaminants to the Arctic. As a result there will be likely increases in POP exposure of Arctic wildlife and human populations, while exposure to vector-borne diseases and zoonoses may increase as well through range expansion and introduction from invasive species. Broad, and nevertheless in-depth studies on the occurrence and human health risk of Arctic zoonoses, and their interactive effects with climate change and contaminant exposure are pending, as well as an increased effort to educate the relevant groups of the public regarding safe handling of wildlife.

\begin{abstract}
Abbreviations
AMAP: arctic monitoring and assessment program; BFRs: brominated flame retardants; BMD: bone mineral density; $\mathrm{CHL}$ : chlordane; Hg: mercury; IL: interleukin; IgG: immunoglobulin G; NMDA: N-methyl-D-aspartic acid; OH-PCBs: hydroxylated PCBs; OCPs: organochlorine pesticides; PCBs: polychlorinated biphenyls; PFASs: poly- and perfluoralkyl substances; PFOS: perfluorooctane sulfonate; PFCAs: poly- and perfluorocarboxylic acid; POPs: persistent organic pollutants; QUS: quantitative ultrasound parameters; TEQ: dioxin toxic equivalency factor; TDI: tolerable daily intake.
\end{abstract}

\section{Authors' contributions}

CS designed the review and produced the 1st draft and further revisions and submission of manuscript. RJL dealt with the precision of environmental contaminants, BMJ with the multiple stressors' framework, JPD with the immune sections, IE with the ecological framework, EAR with zoonosis, KG with PBPK modelling, BS with steroid hormones and RD with modelling and ecosystem effects. All authors read and approved the final manuscript.

\section{Authors' information}

CS is a wildlife veterinarian focusing on industrial chemicals and health effects in the Arctic. RJL is an environmental chemist focusing on legacy and emergent environmental chemicals in the Arctic and North America. BMJ is a wildlife biologist working on birds and marine mammals in the Arctic with a special focus on the thyroid hormone system. JPD is working on immune toxicology in North Atlantic predators. IE is ecologist focusing on food web dynamics and energy and nutrient flow. EAR is DVM with insights to infectious diseases in the Arctic. KG is specialised in applying PBPK modelling to contaminants in Arctic ecosystem wildlife. BS is specialised in analyses and interpretation of steroid hormones in Arctic predators. RD is wildlife biologist with insights to marine mammal biology and contaminant exposure.

\footnotetext{
Author details

${ }^{1}$ Department of Bioscience, Arctic Research Centre (ARC), Aarhus University, Faculty of Science and Technology, Frederiksborgvej 399, PO Box 358, 4000 Roskilde, Denmark. ${ }^{2}$ Ecotoxicology and Wildlife Health Division, Environment and Climate Change Canada, National Wildlife Research Centre Carleton University, Ottawa, ON K1A OH3, Canada. ${ }^{3}$ Department of Biology, Norwegian University of Science and Technology, 7491 Trondheim, Norway. ${ }^{4}$ Department of Arctic Technology, The University Centre in Svalbard, PO Box 156, 9171 Longyearbyen, Norway. ${ }^{5}$ Toxicology Laboratory, Department
} 
of Pharmacy, Faculty of Health and Medical Sciences, University of Copenhagen, Universitetsparken 2, 2100 Copenhagen, Denmark.

\section{Competing interests}

The authors declare that they have no competing interests.

\section{Availability of data and materials}

Not applicable.

\section{Consent for publication}

Not applicable.

\section{Ethics approval and consent to participate}

Not applicable.

\section{Funding}

Nordic Council of Ministers (NMR NORDEN) is acknowledged for financial support to the project entitled Infectious Zoonotic Diseases Transmissible from harvested Wildlife to humans in the European Arctic (ZORRO). We also acknowledge BONUS BALTHEALTH that has received funding from BONUS (Art. 185), funded jointly by the EU, Innovation Fund Denmark (Grants 618000001B and 6180-00002B), Forschungszentrum Jülich GmbH, German Federal Ministry of Education and Research (Grant FKZ 03F0767A), Academy of Finland (Grant 311966) and Swedish Foundation for Strategic Environmental Research (MISTRA).

\section{Publisher's Note}

Springer Nature remains neutral with regard to jurisdictional claims in published maps and institutional affiliations.

Received: 3 November 2017 Accepted: 8 December 2017 Published online: 16 December 2017

\section{References}

1. AMAP. Arctic Monitoring and Assessment Programme: AMAP assessment report_-arctic pollution issues 1998; Oslo 1998. http://www. amap.no.

2. AMAP. Arctic Monitoring and Assessment Programme: AMAP assessment 2002-human health in the Arctic 2003; Oslo 2003. http://www. amap.no.

3. AMAP. Arctic Monitoring and Assessment Programme: AMAP assessment 2002 - persistent organic pollutants in the Arctic 2004; Oslo 2004. http://www.amap.no.

4. AMAP. Arctic Monitoring and Assessment Programme: AMAP assessment 2002 - heavy metals in the Arctic 2005; Oslo 2005. http://www. amap.no.

5. AMAP. Arctic Monitoring and Assessment Programme: AMAP assessment 2009_human health in the Arctic 2009; Oslo 2009. http://www. amap.no.

6. AMAP. Arctic Monitoring and Assessment Programme: AMAP assessment 2013 -human health in the Arctic 2013; Oslo 2015. http://www. amap.no.

7. Letcher RJ, Bustnes JO, Dietz R, Jenssen BM, Jørgensen EH, Sonne C, et al. Effects assessment of persistent organohalogen contaminants in Arctic wildlife and fish. Sci Total Environ. 2010:408:2995-3043.

8. Sonne C. Health effects from long-range transported contaminants in Arctic top predators: an integrated review based on studies of polar bears and relevant model species. Environ Int. 2010;36:461-91.

9. Muir DCG, de Wit CA. Trends of legacy and new persistent organic pollutants in the circumpolar Arctic: overview, conclusions, and recommendations. Sci Total Environ. 2010;408:3044-51.

10. Dietz R, Outridge PM, Hobson KA. Anthropogenic contribution to mercury levels in present-day Arctic animals-a review. Sci Total Environ. 2009:407:6120-31.

11. Dietz R, Basu N, Braune B, O'Hara T, Letcher R, Scheuhammer T, et al. What are the toxicological effects of mercury in Arctic biota? Sci Total Environ. 2013;443:775-90.
12. Dietz R, Rigét FF, Sonne C, Born EW, Bechshøft T, McKinney MA, et al. Part 2: three decades (1984-2010) of flame retardant trends in East Greenland polar bears (Ursus maritimus). Environ Int. 2013;59:494-500.

13. Letcher RJ, Morris AD, Dyck M, Sverko E, Reiner E, Blair DAD, et al. Legacy and (re)emerging halogenated persistent organic pollutants in polar bears from a contamination hotspot in the Arctic, Hudson Bay Canada. Sci Total Environ. 2018;610-611:121-36.

14. Rigét F, Vorkamp K, Bossi R, Sonne C, Letcher RJ, Dietz R. Twenty years of monitoring of persistent organic pollutants in Greenland biota. A review. Environ Pollut. 2016;217:114-23.

15. Pedro S, Boba C, Dietz R, Sonne C, Rosing-Asvid A, Hansen M, et al. Blubber-depth distribution and bioaccumulation of PCBs and organochlorine pesticides in Arctic-invading killer whales. Sci Total Environ. 2017;601-602:237-46.

16. Butt CM, Berger U, Bossi R, Tomy GT. Levels and trends of poly- and perfluorinated compounds in the Arctic environment. Sci Total Environ. 2010;408:2936-65.

17. Houde M, De Silva AO, Muir DCG, Letcher RJ. Monitoring of perfluorinated compounds in aquatic biota: an updated review. Environ Sci Technol. 2011;45:7962-73.

18. Bechshøft T $\varnothing$, Jakobsen J, Sonne C, Dietz R. Distribution of vitamin A (retinol) and $\mathrm{E}$ (a-tocopherol) in polar bear kidney: implications for biomarker studies. Sci Total Environ. 2011;409:3508-11.

19. Bechshøft TØ, Sonne C, Jakobsen J, Rigét FF, Born EW, Letcher RJ, et al. Vitamins $A$ and $E$ in liver, kidney, and whole blood from organohalogen exposed East Greenland polar bears sampled 1994-2008: reference values and temporal trends. Polar Biol. 2016;39:743-54.

20. Kirkegaard M, Sonne C, Dietz R, Jenssen BM, Letcher RJ. Organohalogens in a whale blubber supplemented diet reduce hepatic retinol and renal tocopherol concentrations in Greenland sled dogs. J Toxicol Environ Health Part A. 2010;73:773-86.

21. Kirkegaard M, Sonne C, Dietz R, Jenssen BM, Leifsson PS, Jensen JEB, et al. Testosterone concentrations and male genital organ morphology in Greenland sled dogs (Canis familiaris) dietary exposed to organohalogen contaminants. Toxicol Environ Chem. 2010;92:955-67.

22. Sonne C, Kirkegaard M, Jacobsen J, Jenssen BM, Letcher RJ, Dietz R. Altered 25-hydroxyvitamin D3 in liver tissue from Greenland sledge dogs (Canis familiaris) dietary exposed to organohalogen polluted minke whale (Balaenoptera acuterostrata) blubber. Ecotoxicol Environ Saf. 2014;104:403-8.

23. Sonne C, Dietz R, Rigét FF, Letcher RJ, Munk Pedersen K, Styrishave B. Steroid hormones in blood plasma from Greenland sledge dogs (Canis familiaris) dietary exposed to organohalogen polluted minke whale (Balaenoptera acuterostrata) blubber. Toxicol Environ Chem. 2014;96:273-86.

24. Sonne C, Andersen-Ranberg E, Rajala EL, Agerholm JS, BonefeldJørgensen E, Desforges JP, et al. Prevalence of antibodies against Brucella spp. in West Greenland polar bears (Ursus maritimus) and East Greenland muskoxen (Ovibos moschatus). Polar Biol (In review).

25. Sonne C, Andersen-Ranberg E, Rajala EL, Agerholm JS, BonefeldJørgensen E, Desforges JP, et al. Seroprevalence for Brucella spp. in Baltic ringed seals (Phoca hispida) and East Greenland harp (Pagophilus groenlandicus) and hooded (Cystophora cristata) seals. Vet Immunol ImmunoPathol (In review).

26. Brown TM, Macdonald RW, Muir DCG, Letcher RJ. The distribution and trends of persistent organic pollutants and mercury in marine mammals from Canada's Eastern Arctic. Sci Total Environ. 2017;618:500-17. https://doi.org/10.1016/j.scitotenv.2017.11.052.

27. Dietz R, Gustavson K, Sonne C, Desforges JP, Rigét FF, McKinney MA, et al. Physiologically-based pharmacokinetic modelling of immune, reproductive and carcinogenic effects from contaminant exposure in polar bears (Ursus maritimus). Environ Res. 2015;140:45-55.

28. Landrigan PJ, Fuller R, Acosta NJR, Adeyi O, Arnold R, Basu N, et al. The lancet commission on pollution and health. 2017.

29. Grandjean P, Landrigan PJ. Developmental neurotoxicity of industrial chemicals. Lancet. 2006:368(9553):2167-78.

30. Jenssen BM, Dehli Villanger G, Gabrielsen KM, Bytingsvik J, Ciesielski TM, Sonne C, et al. Anthropogenic flank attack on polar bears: interacting consequences of climate warming and pollutant exposure. Front Ecol. 2015:3:1-7. 
31. Sonne C, Letcher RJ, Bechshøft T $\varnothing$, Rigét FF, Muir DCG, Leifsson PS, et al. Two decades of biomonitoring polar bear health in Greenland: a review. Acta Vet Scan. 2012;54:S15.

32. Polischuk SC, Norstrom RJ, Ramsay MA. Body burdens and tissue concentrations of organochlorines in polar bears (Ursus maritimus) vary during seasonal fasts. Environ Pollut. 2002;118:29-39.

33. Tartu S, Bourgeon S, Aars J, Andersen M, Polder A, Thiemann GW, Welker $J M$, Routti H. Sea ice-associated decline in body condition leads to increased concentrations of lipophilic pollutants in polar bears (Ursus maritimus) from Svalbard, Norway. Sci Total Environ. 2017;576:409-19.

34. Bytingsvik J, Lie $E$, Aars J, Derocher AE, Wiig $\varnothing$, Jenssen BM. PCBs and $\mathrm{OH}-\mathrm{PCBs}$ in polar bear mother-cub pairs: a comparative plasma levels in 1998 and 2008. Sci Total Environ. 2012:417:117-28.

35. Dietz R, Rigét FF, Sonne C, Letcher RJ, Born EW, Muir DCG. Seasona and temporal trends in polychlorinated biphenyls and organochlorine pesticides in East Greenland polar bears (Ursus maritimus), 1990-2001. Sci Total Environ. 2004;331:107-24

36. Dietz R, Rigét FF, Sonne C, Muir DCG, Backus S, Born EW, et al. Age and seasonal variability of polybrominated diphenyl ethers in freeranging East Greenland polar bears (Ursus maritimus). Environ Pollut. 2007;146:177-84.

37. Muir DCG, Backus S, Derocher AE, Dietz R, Evans TJ, Gabrielsen GW, et al. Brominated flame retardants in polar bears (Ursus maritimus) from Alaska, the Canadian Arctic, East Greenland, and Svalbard. Environ Sci Technol. 2006:40:449-55.

38. Nuijten RJM, Hendriks AJ, Jenssen BM, Schipper AM. Circumpolar contaminant concentrations in polar bears (Ursus maritimus) and potential population-level effects. Environ Res. 2016;151:50-7.

39. Pavlova V, Grimm V, Dietz R, Sonne C, Vorkamp K, Rigét FF, et al. Modelling population level effects of PCB contamination in East Greenland polar bears. Arch Environ Contam Toxicol. 2016;70:143-54.

40. Pavlova V, Nabe-Nielsen J, Dietz R, Sonne C, Grimm V. PCB contamination as a potential driver of mate-finding associated Allee effect in Svalbard polar bears: the implications from an individual based model. Proc Biol Sci. 2016:283:1843.

41. AMAP. Arctic Monitoring and Assessment Programme: AMAP assessment 2018-persistent organic pollutants in the Arctic 2018; Oslo 2018. http://www.amap.no.

42. Dietz R, Rigét FF, Sonne C, Born EW, Bechshøft T, McKinney MA, Letcher RJ. Part 1: three decades (1984-2010) of legacy contaminant trends in East Greenland polar bears (Ursus maritimus). Environ Int. 2013:59:485-93.

43. Lindh $\mathrm{CH}$, Rylander L, Toft G, Axmon A, Rignell-Hydbom A, Giwercman $A$, et al. Blood serum concentrations of perfluorinated compounds in men from Greenlandic Inuit and European populations. Chemosphere. 2012;88:1269-75.

44. Sonne C, Dietz R, Letcher RJ. Chemical cocktail party in East Greenland: a first time evaluation of human organohalogen exposure from consumption of ringed seal and polar bear tissues and possible health implications. Toxicol Environ Chem. 2013;95:853-9.

45. Wielsoe M, Kern P, Bonefeld-Jorgensen EC. Serum levels of environmental pollutants is a risk factor for breast cancer in Inuit: a case control study. Environ Health. 2017;16:16.

46. Deutch B, Dyerberg J, Pedersen HS, Asmund G, Møller P, Hansen JC. Dietary composition and contaminants in north Greenland, in the 1970s and 2004. Sci Total Environ. 2006;370:372-81.

47. Johansen P, Muir DCG, Asmund G, Rigét FF. Human exposure to contaminants in the traditional Greenland diet. Sci Total Environ. 2004;331:189-206.

48. Nielsen E, Larsen JC, Ladefoged O. Risk assessment of contaminant intake from traditional Greenland food items. Danish Veterinary and Food Administration; 2006. p. 180. http://www.dfvf.dk.

49. AMAP. Arctic Monitoring and Assessment Programme: AMAP assess ment 2011-mercury in the Arctic 2011; Oslo 2011. http://www.amap. no.

50. Bonefeld-Jørgensen E. Biomonitoring in Greenland: human biomarkers of exposure and effects - a short review. Rural Remote Health. 2010;10:1362

51. Sonne C, Gustavson K, Rigét FF, Krüger T, Dietz R, Bonefeld-Jørgensen E. Physiologically based pharmacokinetic modeling of contaminants in Greenlanders: a new tool for monitoring levels and possible health effects? Environ Int. 2014;64:91-7.

52. Polder A, Gabrielsen GW, Odland JØ, Savinova TN, Tkachev A, Løken KB, Skaare JU. Spatial and temporal changes of chlorinated pesticides, PCBs, dioxins (PCDDs/PCDFs) and brominated flame retardants in human breast milk from northern Russia. Sci Total Environ. 2008;391:41-54.

53. Bonefeld-Jørgensen E, Long M, Bossi R, Ayotte P, Asmund G, Krüger $T$, et al. Perfluorinated compounds are related to breast cancer risk in Greenlandic Inuit: a case control study. Environ Health. 2011;10:88.

54. Grandjean P, Andersen EW, Budtz-Jørgensen E, Nielsen F, Mølbak K, Weihe $P$, et al. Serum vaccine antibody concentrations in children exposed to perfluorinated compounds. JAMA. 2012;307:391-7.

55. Long M, Bossi R, Bonefeld-Jørgensen EC. Levels and temporal trends of perfluoroalkyl acids in human serum from Greenland Inuit. Int J Circumpolar Health. 2012;71:17998.

56. Rand AA, Mabury SA. Is there a human health risk associated with indirect exposure to perfluoroalkyl carboxylates (PFCAs)? Toxicology. 2017;375:28-36.

57. Wilkinson JL, Hooda PS, Barker J, Barton S, Swinden J. Ecotoxic pharmaceuticals, personal care products, and other emerging contaminants: a review of environmental, receptor-mediated, developmental, and epigenetic toxicity with discussion of proposed toxicity to humans. Crit Rev Environ Sci Technol. 2016;46:336-81.

58. Sonne C, Leifsson PS, Dietz R, Born EW, Letcher RJ, Kirkegaard M, et al. Enlarged clitoris in wild polar bears (Ursus maritimus) can be misdiagnosed as pseudohermaphroditism. Sci Total Environ. 2005;337:45-58.

59. Grandjean P, Satoh H, Murata K, Eto K. Adverse effects of methylmercury: environmental health research implications. Environ Health Perspect. 2010;118:1137-45

60. Dietz R, Born EW, Rigét FF, Aubail A, Sonne C, Drimmei RC, et al. Temporal trends and future predictions of mercury concentrations in Northwest Greenland polar bear (Ursus maritimus) hair. Environ Sci Technol. 2011;45:1458-65

61. McKinney MA, Iverson SJ, Fisk AT, Sonne C, Rigét FF, Letcher RJ, et al. Global change effects on the long-term feeding ecology and contaminant exposures of East Greenland polar bears. Glob Change Biol. 2013;19:2360-72.

62. Letcher RJ, Boisvert G, Dyck M, Sonne C, Dietz R. Polar bears from two Arctic pollution hot spots: Comparison of recent levels of established and new perfluorinated sulfonic and carboxylic acids and precursors. Sci Total Environ. 2017 (In review)

63. Rigét FF, Braune B, Bignert A, Wilson S, Aars J, Andersen M, et al. Temporal trends of $\mathrm{Hg}$ in Arctic biota, an update. Sci Total Environ. 2011;409:3520-6.

64. Rigét FF, Bossi R, Sonne C, Vorkamp K, Dietz R. Trends of perfluorochemicals in Greenland ringed seals and polar bears: indications of decreasing trends. Chemosphere. 2013;93:1607-14.

65. Pertoldi C, Sonne C, Wiig Ø, Baagøe HJ, Loeschcke V, Bechshøft T East Greenland and Barents Sea polar bears (Ursus maritimus): adaptive variation between two populations using skull morphometrics as an indicator of gene flow. Hereditas. 2012;149:99-107.

66. Sonne C, Dyck M, Rigét FF, Bech-Jensen JE, Hyldstrup L, Letcher RJ, et al Penile density and globally used chemicals in Canadian and Greenland polar bears. Environ Res. 2015;137:287-91.

67. Andersen-Ranberg. Metals and flukes in West Greenland ringed seals (Pusa hispida) - a histopathological, toxicological, parasitological and molecular study. M.Sc. thesis 2014, University of Copenhagen; p. 109.

68. Sonne-Hansen C, Dietz R, Leifsson PS, Hyldstrup L, Rigét FF. Cadmium toxicity to ringed seals (Phoca hispida) — an epidemiological study of possible cadmium induced nephropathy and osteodystrophy in ringed seals (Phoca hispida) from Qaanaaq in Northwest Greenland. Sci Total Environ. 2002;295:167-81

69. Woshner VM. Concentrations and interactions of selected elements in tissues of four marine mammal species harvested by Inuit hunters in arctic Alaska, with an intensive histologic assessment, emphasizing the beluga whale. University of Illinois at Urbana-Champaign 2000; Urbana, Illinois 2000, Ph.D. Dissertation.

70. Woshner VM, O'Hara TM, Bratton GR, Suydam RS, Beasley VR. Concentrations and interactions of selected essential and non-essentia 
elements in bowhead and beluga whales of Arctic Alaska. J Wildl Dis. 2001;37:693-710.

71. Woshner VM, O'Hara TM, Bratton GR, Beasley VR. Concentrations and interactions of selected essential and non-essential elements in ringed seals and polar bears of Arctic Alaska. J Wildl Dis. 2001;37:711-21.

72. Woshner VM, Knott K, Wells R, Willetto C, Swor R, O'Hara T. Mercury and selenium in blood and epidermis of bottlenose dolphins (Tursiops truncatus) from Sarasota Bay, FL: interaction and relevance to life history and hematologic parameters. EcoHealth. 2008;5:1-11.

73. Donaldson SG, Van Oostdam J, Tikhonov C, Feeley M, Armstrong B, Ayotte $\mathrm{P}$, et al. Environmental contaminants and human health in the Canadian Arctic. Sci Total Environ. 2010;408:5165-234.

74. Gebbink WA, Sonne C, Dietz R, Kirkegaard M, Rigét FF, Born EW, et al. Tissue-specific congener composition of organohalogen and metabolite contaminants in East Greenland polar bears (Ursus maritimus). Environ Pollut. 2008;152:621-9.

75. Lagueux J, Pereg D, Ayotte P, Dewailly E, Poirier GG. Cytochrome P450 CYP1A1 enzyme activity and DNA adducts in placenta of women environmentally exposed to organochlorines. Environ Res. 1999;80:369-82.

76. Medehouenou TC, Larochelle C, Dumas P, Dewailly E, Ayotte P. Determinants of AhR-mediated transcriptional activity induced by plasma extracts from Nunavik Inuit adults. Chemosphere. 2010;80:75-82.

77. Sandau CD, Ayotte P, Dewailly E, Duffe J, Norstrom RJ. Pentachlorophenol and hydroxylated polychlorinated biphenyl metabolites in umbilical cord plasma of neonates from coastal populations in Québec. Environ Health Perspect. 2002;110:411-7.

78. Sonne C, Dietz R, Born EW, Rigét FF, Kirkegaard M, Hyldstrup L, et al. Is bone mineral composition disrupted by organochlorines in East Greenland polar bears (Ursus maritimus)? Environ Health Perspect. 2004;112:1711-6.

79. Herlin M, Kalantari F, Stern N, Sand S, Larsson S, Viluksela M, et al. Quantitative characterization of changes in bone geometry, mineral density and bio-mechanical properties in two rat strains with different Ah-receptor structures after long-term exposure to 2,3,7,8-tetrachlorodibenzo-p-dioxin. Toxicology. 2010;29:1-11.

80. Lind PM, Bergman A, Olsson M, Orberg J. Bone mineral density in male Baltic grey seal (Halichoerus grypus). Ambio. 2003;32:385-8.

81. Lind PM, Milnes MR, Lundberg R, Bermudez D, Örberg J, Guillette LJ. Abnormal bone composition in female juvenile American alligators from a pesticide-polluted lake (Lake Apopka, Florida). Environ Health Perspect. 2004;112:359-62.

82. Côté S, Ayotte P, Dodin S, Blanchet C, Mulvad G, Petersen HS, et al. Plasma organochlorine concentrations and bone ultrasound measurements: a cross-sectional study in peri-and postmenopausal Inuit women from Greenland. Environ Health. 2006;5:33.

83. Paunescu AC, Dewailly E, Dodin S, Nieboer E, Ayotte P. Dioxin-like compounds and bone quality in Cree women of Eastern James Bay (Canada): a cross-sectional study. Environ Health. 2013;12:54.

84. Sonne C, Letcher RJ, Jenssen BM, Desforges JP, Eulaers I, Andersen-

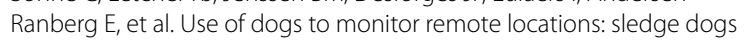
and the Artic environment. Springer Book (In review).

85. Dallaire R, Dewailly E, Ayotte P, Muckle G, Laliberte C, Bruneau S. Effects of prenatal exposure to organochlorines on thyroid hormone status in newborns from two remote coastal regions in Quebec, Canada. Environ Res. 2008;108:387-92.

86. Gustavson L, Ciesielski TM, Bytingsvik J, Styrishave B, Hansen M, Lie E, et al. Hydroxylated polychlorinated biphenyls decrease circulating steroids in female polar bears (Ursus maritimus). Environ Res. 2015;138:191-201.

87. Ciesielski TM, Hansen IT, Bytingsvik J, Hansen M, Lie E, Aars J, et al. Relationships between POPs, biometrics and circulating steroids in male polar bears (Ursus maritimus) from Svalbard. Environ Pollut. 2017;230:598-608.

88. Sonne C, Leifsson PS, Dietz R, Born EW, Letcher RJ, Hyldstrup L, et al. Xenoendocrine pollutants may reduce size of sexual organs in East Greenland polar bears (Ursus maritimus). Environ Sci Technol. 2006;40:5668-74.

89. Desforges JPW, Sonne C, Levin M, Siebert U, De Guise S, Dietz R. Immunotoxic effects of environmental pollutants in marine mammals. Environ Int. 2016;86:126-39.
90. Sonne C, Torjesen PA, Berg KA, Fuglei E, Muir DCG, Jenssen BM, et al. Exposure to persistent organic pollutants reduces testosterone concentrations and affects sperm viability and morphology during the mating peak-period in a controlled experiment on farmed Arctic foxes (Vulpes lagopus). Environ Sci Technol. 2017;51:4673-80.

91. Janeway CA, Travers P, Walport M, Shlomchik M. Immune biology-the immune system in health and disease. 5th ed. New York: Garland Publishing, Taylor and Francis; 2001. p. 732.

92. Vos JG, Luster MI. Immune alterations. In: Kimbrough RD, Jensen AD, editors. Halogenated biphenyls, terphenyls, naphthalenes, dibenzodioxins, and related products. Amsterdam: Elsevier; 1989.

93. Hertz-Picciotto I, Park HY, Dostal M, Kocan A, Trnovec T, Sram R. Prenatal exposures to persistent and non-persistent organic compounds and effects on immune system development. Basic Clin Pharmacol Toxicol. 2008; 102:146-54.

94. Klecha AJ, Barreiro Arcos ML, Frick L, Genaro AM, Cremaschi G. Immuneendocrine interactions in autoimmune thyroid diseases. Neuroimmunomodulation. 2008:15:68-75.

95. Tryphonas H. Immunotoxicity of polychlorinated-biphenyls-present status and future considerations. Exp Clin Immunogenet. 1994;11:149-62.

96. Lie E, Larsen HJS, Larsen S, Johansen GM, Derocher AE, Lunn NJ, et al. Does high organochlorine (OC) exposure impair the resistance to infection in polar bears (Ursus maritimus)? Part l: effect of OCs on the humoral immunity. J Toxicol Environ Health A. 2004;67:555-82.

97. Lie E, Larsen HJS, Larsen S, Johansen GM, Derocher AE, Lunn NJ, et al. Does high organochlorine $(\mathrm{OC})$ exposure impair the resistance to infection in polar bears (Ursus maritimus)? Part II: possible effect of OCs on mitogen- and antigen-induced lymphocyte proliferation. J Toxicol Environ Health A. 2005;68:457-84.

98. Routti H, Arukwe A, Jenssen BM, Letcher RJ, Nyman M, Bäckman C, et al. Comparative endocrine disruptive effects of contaminants in ringed seals (Phoca hispida) from Svalbard and the Baltic Sea. Comp Biochem Physiol C Toxicol Pharmacol. 2010;152:306-12.

99. Brown TM, Ross PS, Reimer KJ, Veldhoen N, Danger NJ, Fisk AT, et al. PCB related effects thresholds as derived through gene transcript profiles in locally contaminated ringed seals (Pusa hispida). Environ Sci Technol. 2014;48:12952-61.

100. Levin M, Gebhard E, Jasperse L, Desforges JP, Dietz R, Sonne C, et al. Immunomodulatory effects of exposure to polychlorinated biphenyls and perfluoroalkyl acids in East Greenland ringed seals (Pusa hispida). Environ Res. 2016;151:244-50.

101. Frouin H, Loseto LL, Stern G, Haulena M, Ross PS. Mercury toxicity in beluga whale lymphocytes: limited effects of selenium protection. Aquat Toxicol. 2012;109:185-93.

102. Parkinson AJ. The Arctic human health initiative: a legacy of the international polar year 2007-2009. Int J Circumpolar Health. 2013;72:10.

103. Dallaire F, Dewailly E, Vézina C, Ayotte P, Muckle G, Bruneau S. Effect of prenatal exposure to polychlorinated biphenyls on incidence of acute respiratory infections in preschool Inuit children. Environ Health Perspect. 2006;114:1301-5.

104. Dewailly É, Ayotte P, Bruneau S, Laliberté C, Gingras S, Belles-Isles M, et al. Susceptibility to infections and immune status in Inuit infants exposed to organochlorines. Environ Health Perspect. 2000;108:205-11.

105. Dallaire R, Dewailly E, Ayotte P, Forget-Dubois N, Jacobson SW, Jacobson JL, et al. Growth in Inuit children exposed to polychlorinated biphenyls and lead during fetal development and childhood. Environ Res. 2014;134:17-23.

106. Weisglas-Kuperus N. Neurodevelopmental, immunological and endocrinological indices of perinatal human exposure to PCBs and dioxins. Chemosphere. 1998;37:1845-53.

107. Grandjean P, Landrigan PJ. Neurobehavioural effects of developmental toxicity. Lancet. 2014;13:330-8.

108. Greaves AK, Letcher RJ, Sonne C, Dietz R, Born EW. Tissue-specific concentrations and patterns of perfluoroalkyl carboxylates and sulfonates in East Greenland polar bears. Environ Sci Technol. 2012:46:11575-83.

109. Greaves AK, Letcher RJ, Sonne C, Dietz R. Brain region distribution and patterns of bioaccumulative perfluoroalkyl carboxylates and sulfonates in East Greenland polar bears (Ursus maritimus). Environ Toxicol Chem. 2013;32:713-22. 
110. Krey A, Kwan M, Chan HM. Mercury speciation in brain tissue of polar bears (Ursus maritimus) from the Canadian Arctic. Environ Res. 2012;114:24-30.

111. Pedersen KE, Basu N, Letcher RJ, Greaves AK, Sonne C, Dietz R, et al. Brain region-specific perfluoroalkylated sulfonate (PFSA) and carboxylic acid (PFCA) accumulation and neurochemical biomarker responses in East Greenland polar bears (Ursus maritimus). Environ Res. 2015;138:22-31.

112. Pedersen KE, Basu N, Letcher RJ, Sonne C, Dietz R, Styrishave B. Per- and polyfluoroalkyl substances (PFASs) —new endocrine disruptors in polar bears (Ursus maritimus)? Environ Int. 2016;138:22-31.

113. Fonnum F, Mariussen E. Mechanisms involved in the neurotoxic effects of environmental toxicants such as polychlorinated biphenyls and brominated flame retardants. J Neurochem. 2009;111:1327-47.

114. Mariussen E. Neurotoxic effects of perfluoroalkylated compounds: mechanisms of action and environmental relevance. Arch Toxicol. 2012;86:1349-67.

115. Bollati V, Baccarelli A. Environmental epigenetics. Heredity. 2010;105:105-12.

116. Crews D. Epigenetic modifications of brain and behavior: theory and practice. Horm Behav. 2011;59:393-8.

117. Mill J, Petronis A. Pre- and peri-natal environmental risks for attentiondeficit hyperactivity disorder (ADHD): the potential role of epigenetic processes in mediating susceptibility. J Child Psychol Psychiatry. 2008:49:1020-30.

118. Basu N, Scheuhammer AM, Sonne C, Dietz R, Letcher RJ. Is mercury in the environment of neurotoxic concern to polar bears? Environ Toxicol Chem. 2009;28:133-40.

119. Pilsner JR, Lazarus AL, Nam D, Letcher RJ, Scheuhammer T, Sonne C, et al. Mercury-associated DNA hypomethylation in polar bear brains via the LUminometric Methylation Assay (LUMA): a sensitive method to study epigenetics in wildlife. Mol Ecol. 2010;19:307-14.

120. Siegel GJ, Albers RW, Brady ST, Price DL. Basic neurochemistry. Molecular, cellular and medical aspects. 7th ed. Burlington: Elsevier Academic; 2006

121. Ahmed El, Zehr JL, Schulz KM, Lorenz BH, Don Carlos LL, Sisk CL. Pubertal hormones modulate the addition of new cells to sexually dimorphic brain regions. Nat Neurosci. 2008;11:995-7.

122. Zoeller RT, Crofton KM. Mode of action: developmental thyroid hormone insufficiency - neurological abnormalities resulting from exposure to propylthiouracil. Crit Rev Toxicol. 2005;35:771-81.

123. Bytingsvik J, Simon E, Leonards PEG, Lamoree M, Lie E, Aars J, et al. Transthyretin-binding activity of contaminants in blood from polar bear (Ursus maritimus) cubs. Environ Sci Technol. 2013:47:4778-86.

124. Simon E, van Velzen M, Brandsma SH, Lie E, Løken K, de Boer J, et al. Effect-directed analysis to explore the polar bear exposome: identification of thyroid hormone disrupting compounds in plasma. Environ Sci Technol. 2013;47:8902-12.

125. Rodier PM. Developing brain as a target of toxicity. Environ Health Perspect. 1995;103:73-6.

126. McKinney MA, Pedro S, Dietz R, Sonne C, Fisk AT, Roy D, et al. A review of ecological impacts of global climate change on persistent organic pollutant and mercury pathways and exposures in arctic marine ecosystems. Curr Zool. 2015;61:617-28.

127. Burek KA, Gulland FMD, O'Hara TM. Effects of climate change on Arctic marine mammal health. Ecol Appl. 2008;18:S126-34.

128. Harvell CD, Mitchell CE, Ward JR, Altizer S, Dobson AP, Ostfeld RS, et al. Climate warming and disease risks for terrestrial and marine biota. Science. 2002;296:2158-62

129. Dudley JP, Hoberg EP, Jenkins EJ, Parkinson AJ. Climate change in the North American Arctic: a One Health perspective. EcoHealth. 2015:12:713-25.

130. Bradley M, Kutz SJ, Jenkins E, O'Hara TM. The potential impact of climate change on infectious diseases of Arctic fauna. Int J Circumpolar Health. 2005;64:468-77

131. Greer A, Ng V, Fisman D. Climate change and infectious diseases in North America: the road ahead. CMAJ. 2008;178:715-22.

132. Jenkins EJ, Castrodale LJ, de Rosemond SJ, Dixon BR, Elmore SA, Gesy $\mathrm{KM}$, et al. Tradition and transition: parasitic zoonoses of people and animals in Alaska, northern Canada, and Greenland. Adv Parasitol. 2013;82:33-204

133. Derocher AE, Aars J, Amstrup SC, Cutting A, Lunn NJ, Molnár PK, et al. Rapid ecosystem change and polar bear conservation. Conserv Lett. 2013;6:368-75

134. Durner GM, Douglas DC, Nielson RM, Amstrup SC, McDonald TL, Stirling I, et al. Predicting 21st-century polar bear habitat distribution from global climate models. Ecol Monogr. 2009;79:25-58.

135. Molnár PK, Derocher AE, KlanjscekT, Lewis MA. Predicting climate change impacts on polar bear litter size. Nat Commun. 2011;2:186.

136. Hamilton SG, de la Guardia LC, Derocher AE, Sahanatien V, Tremblay B, Huard D. Projected polar bear sea ice habitat in the Canadian Arctic Archipelago. PLoS ONE. 2014;9:e113746.

137. Amstrup SC, Marcot BG, Douglas DC. A Bayesian network modeling approach to forecasting the 21st century worldwide status of polar bears. In: DeWeaver ET, Bitz CM, Tremblay L-B, editors. Arctic sea ice decline: observations, projections, mechanisms, and implications, vol. 180. Washington, DC: American Geophysical Union; 2018. p. 213-68.

138. Olsen GH, Mauritzen M, Derocher AE, Sørmo EG, Skaare JU, Wiig O, et al. Space-use strategy is an important determinant of PCB concentrations in female polar bears in the Barents Sea. Environ Sci Technol. 2003:37:4919-24.

139. van Beest FM, Aars J, Routti H, Lie E, Andersen M, Pavlova V, Sonne $\mathrm{C}$, et al. Spatiotemporal variation in home range size of female pola bears and correlations with individual contaminant load. Polar Biol. 2016;39:1479-89.

140. McKinney MA, Peacock E, Letcher RJ. Sea ice-associated diet change increases the levels of chlorinated and brominated contaminants in polar bears. Environ Sci Technol. 2009:43:4334-9.

141. Gormezano LJ, Rockwell RF. What to eat now? Shifts in polar bear diet during the ice-free season in western Hudson Bay. Ecol Evol. 2013;3:3509-23.

142. Iles DT, Petersen SL, Gormezano U, Koons DN, Rockwell RF. Terrestrial predation by polar bears: not just a wild goose chase. Polar Biol. 2013;36:1373-9.

143. Iverson SA, Gilchrist HG, Smith PA, Gaston AJ, Forbes MR. Longer ice-free seasons increase the risk of nest depredation by polar bears for colonial breeding birds in the Canadian Arctic. Proc R Soc B. 2014;281:20133128

144. MacKenzie BR, Payne MR, Boje J, Hoyer JL, Siegstad H. A cascade of warming impacts brings bluefin tuna to Greenland waters. Glob Chang Biol. 2014;20:2484-91.

145. Valdimarsson $\mathrm{H}$, Astthorsson OS, Palsson J. Hydrographic variability in Icelandic waters during recent decades and related changes in distribution of some fish species. ICES J Mar Sci. 2012;69:816-25.

146. Carrie J, Wang F, Sanei H, Macdonald RW, Outridge PM, Stern GA. Increasing contaminant burdens in an arctic fish, burbot (Lota lota), in a warming climate. Environ Sci Technol. 2010;44:316-22.

147. Macdonald RW, Harner T, Fyfe J. Recent climate change in the Arctic and its impact on contaminant pathways and interpretation of temporal trend data. Sci Total Environ. 2005:342:5-86.

148. IOM. Global climate change and extreme weather events: understanding the contributions to infectious disease emergency. Washington, DC: The National Academic Press, Institute of Medicine; 2008. p. 280.

149. Parkinson AJ, Butler JC. Potential impacts of climate change on infectious diseases in the Arctic. Int J Circumpolar Health. 2005;64:478-86.

150. Tryland M, Nesbakken T, Robertson L, Grahek-Ogden D, Lunestad BT. Human pathogens in marine mammal meat-a northern perspective. Zoonoses Publ Health. 2013;61:377-94.

151. Jenssen BM. Marine pollution: the future challenge is to link human and wildlife studies. Environ Health Perspect. 2003;111:A198-9.

152. Jenssen BM. Endocrine-disrupting chemicals and climate change: a worst-case combination for Arctic marine mammals and seabirds? Environ Health Perspect. 2006;114:76-80.

153. Weihe P, Debes F, Halling J, Petersen MS, Muckle G, Odland J $\varnothing$, et al. Health effects associated with measured levels of contaminants in the Arctic. Int J Circumpolar Health. 2016;75:33805. 